\title{
Sistem Informasi PraOutline Tugas Akhir Program Studi Teknik Informatika UM Pontianak
}

\author{
Syarifah Putri Agustini Alkadri ${ }^{1}$, Rizky Wahyu Prasetio ${ }^{2}$ \\ ${ }^{1,2)}$ Program Studi Teknik Informatika, Universitas Muhammadiyah Pontianak \\ Email: ${ }^{1}$ agustini.putri@unmuhpnk.ac.id, ${ }^{2}$ rizky.prasetio@unmuhpnk.ac.id
}

(Naskah masuk: 1 April 2021, diterima untuk diterbitkan: 8 Juni 2021)

\begin{abstract}
ABSTRAK
Salah satu prosedur dalam pengajuan Tugas Akhir adalah mahasiswa wajib untuk membuat proposal tugas akhir (outline). Permasalahan yang ditemui adalah proses pengajuan proposal menjadi terlambat karena mahasiswa tidak dapat menyelesaikan proposal tepat waktu. Situasi pandemi Covid19 serta kesibukan dosen menjadi hambatan bagi mahasiswa untuk melakukan bimbingan tatap muka langsung dengan dosen. Penelitian ini bertujuan membuat prototipe Sistem Informasi Pra-Outline Tugas Akhir mahasiswa yang dapat memudahkan mahasiswa melakukan konsultasi/bimbingan penulisa proposal tugas akhir serta interaksi dengan pihak prodi melalui sistem informasi berbasis web. Metode pengembangan perangkat lunak menggunakan pendekatan prototyping dengan tahapan yaitu pengumpulan data, analisis kebutuhan sistem, desain sistem, implementasi prototipe, pengujian prototipe, review dan perbaikan prototipe dan pengujian pengguna. Prototipe dirancang berbasis web dengan menggunakan Framework Code Ignitier $(\mathrm{Cl})$ dan basis data MySQL, pengujian perangkat lunak menggunakan metode blackbox sementara pengujian pengguna menggunakan User Acceptance Testing (UAT). Pengujian black box menunjukkan keseluruhan fungsional sistem dapat berjalan dengan baik dan sesuai dengan yang diharapkan sementara pengujian UAT memberikan hasil yaitu $>80 \%$ tester memilih kategori sangat memuaskan. Hasil penelitian menunjukkan bahwa prototipe dapat digunakan dengan baik dan mempermudah mahasiswa dalam melakukan konsultasi judul tugas akhir.
\end{abstract}

Kata kunci: Sistem Informasi, Code Ignitier, Outline Mahasiswa.

\begin{abstract}
One of the procedures in submitting a Final Project is that students are required to make a final project proposal (outline). The problem is that the process of submitting proposals is usually late because the students cannot complete their proposals on time. The Covid-19 pandemic situation and the busyness of lecturers are obstacles for the students to conduct face-to-face guidance with the lecturers. This study aims to make a prototype of the student's final project pre-outline information system that facilitates students in conducting consultation / guidance on writing their final project proposals and interacting with the department through a web-based information system. The software development method used a prototyping approach with some stages namely data collection, system requirements analysis, system design, prototype implementation, prototype testing, review and prototype revision and user testing. The designed prototype is a web based information system using the Codelgniter (Cl) Framework and MySQL database. The blackbox method was used as the software testing and the User Acceptance Testing (UAT) was used as the user testing. Black box testing results showed that the overall functional system can run well as expected and the UAT test results showed that more than $80 \%$ of users chose a very satisfying category. It can be concluded that the prototype can run well and make the students consult the final project well.
\end{abstract}

Keywords: Information Systems, Codeigniter, Student Outline. 


\section{Pendahuluan}

Tugas Akhir merupakan salah satu syarat untuk menyelesaikan pendidikan jenjang Sarjana pada Program Studi Teknik Informatika UM Pontianak. Tugas akhir tersebut dapat berbentuk karya tulis ilmiah/penelitian yang memuat ilmu pengetahuan dan kebenaran ilmiah yang menyajikan fakta yang disusun secara sistematis menurut metode penulisan dan menggunakan ragam bahasa ilmiah (Teknik, 2014).

Salah satu prosedur dalam pengajuan Tugas Akhir adalah mahasiswa wajib untuk membuat proposal tugas akhir (outline). Pada Program Studi Teknik Informatika UM Pontianak, prosedur pengajuan tugas akhir melalui beberapa tahapan diantaranya adalah 1). Pengajuan judul tugas akhir 2).Pengecekan kemiripan artikel 3). Pengajuan proposal tugas akhir, dan 4). pelaksanaan seminar proposal tugas akhir. Pada tahap pengajuan judul tugas akhir, mahasiswa diwajibkan membuat draft proposal yang berisi deskripsi judul tugas akhir yang akan diusulkan. Draft tersebut kemudian dilakukan pengecekan kemiripan artikel untuk menghindari plagiat dalam isi proposal. Proposal yang sudah lolos cek plagiat kemudian akan masuk ke sesi seminar proposal Tugas Akhir. Di sesi seminar proposal tugas akhir setiap mahasiswa akan diuji penguasaan materinya oleh dosen penguji dan kemudian dinyatakan lulus/tidak lulus untuk diangkat menjadi judul tugas akhir/skripsi .

Permasalahan yang ditemui adalah proses pengajuan proposal menjadi terlambat karena mahasiswa tidak dapat menyelesaikan proposal tepat waktu. Hal ini dikarenakan mahasiswa merasa bingung dan tidak dapat melakukan konsultasi secara intensif mengenai judul/ topik tugas akhir yang akan diusulkan. Situasi pandemi Covid-19 serta kesibukan dosen menjadi hambatan bagi mahasiswa untuk melakukan bimbingan tatap muka langsung dengan dosen. Pemberlakukan Physical Distancing serta aturan PSBB (Pembatasan Sosial Berskala Besar) membuat keadaan menjadi sulit bagi mahasiswa dalam proses pengerjaan skripsi terutama dalam proses pengumpulan data serta proses bimbingan (Almahfud, 2020).

Kebijakan UM Pontianak untuk melakukan pelayanan akademik, kegiatan PBM dan bimbingan tugas akhir secara jarak jauh (online) membuat mahasiswa melakukan konsultasi secara terpisah dengan masing-masing dosen pembimbing melalui layanan pesan whatsapp, sehingga ide pokok penelitian menjadi kurang terarah. Permasalahan lainnya adalah proses rekap judul mahasiswa yang dilakukan secara manual menggunakan Microsoft Excel sehingga rentan mengalami kesalahan input atau duplikasi judul, karena mahasiswa tidak dapat mengetahui rekam jejak judul yang telah diajukan sebelumnya.

Salah satu bentuk pemanfaatan teknologi informasi untuk mengtasi permasalahan di atas adalah dengan menggunakan sistem informasi. Sistem Informasi merupakan sistem yang berjalan pada suatu organisasi yang meliputi kegiatan transaksi harian yang mendukung fungsi organisasi yang bersifat manajerial dan dapat menyediakan informasi yang diperlukan.(Sutabri, 2012).

Terdapat beberapa penelitian serupa terkait sistem pengusulan judul tugas akhir diantaranya adalah perancangan sistem pengajuan tugas akhir dengan memanfaatkan UML dengan metode waterfall yang menghasilkan sistem informasi yang memudahkan mahasiswa melihat daftar judul yang telah diterima (Kusumaningrum, 2011). Penelitian kedua membahas aplikasi pengajuan proposal tugas akhir dengan menggunakan arsitektur MVC sebagai model 
pengembangan perangkat lunak. Penelitian ini menghasilkan aplikasi pengajuan judul tugas akhir berbasis web yang dapat membantu mahasiswa dalam mengajukan draft proposal outline mengecek informasi berupa hasil proposal serta data pembimbing melalui SMS.(Putra \& Kumaladewi, 2012). Penelitian lainnya digunakan RUP (Rasional Unified Process) sebagai metode untuk menentukan ruang lingkup business case penelitian.Penelitian ini menghasilkan suatu sistem informasi proses tugas akhir yang berbasis web melalui beberapa proses antara lain penentuan business case, pembuatan arsitektur sistem, pengkodean, dan pengujian sistem. Sistem ini dapat digunakan oleh Dosen dan Mahasiswa untuk proses tugas akhir sehingga dapat memudahkan proses konsultasi dan bimbingan tugas akhir (Tuturoong, Sengkey, \& Najoan, 2016).

Berdasarkan uraian di atas, penulis tertarik untuk mengambil judul "Sistem Informasi Pra Outline Tugas Akhir Prodi Teknik Informatika UM Pontianak ". Penelitian ini diharapkan dapat menghasilkan sistem informasi berbasis web yang memudahkan mahasiswa dan dosen dalam kegiatan bimbingan pengajuan judul tugas akhir. Mahasiswa dapat mengajukan topik tugas akhir secara online, kemudian dosen dapat mereview judul dan draft usulan melalui fitur komentar. Setelah itu, pada akhir review dosen dapat memberikan persetujuan pada judul yang diajukan oleh mahasiswa untuk kemudian dapat melanjutkan pada tahapan seminar proposal. Hasil review tersebut juga digunakan sebagai rekomendasi dalam menentukan dosen penguji sesuai dengan kelompok keahlian dosen.

\section{Metodologi}

Metode pengembangan perangkat lunak yang digunakan yaitu metode prototyping dimana akan dilakukan pengujian berulang kali kepada pengguna. Hal ini dilakukan agar pengembang dapat menerima masukan langsung pengguna agar sistem dapat sesuai dengan kebutuhan (Pressman, 2014). Langkah prototyping dapat dilihat pada Gambar 1 berikut.

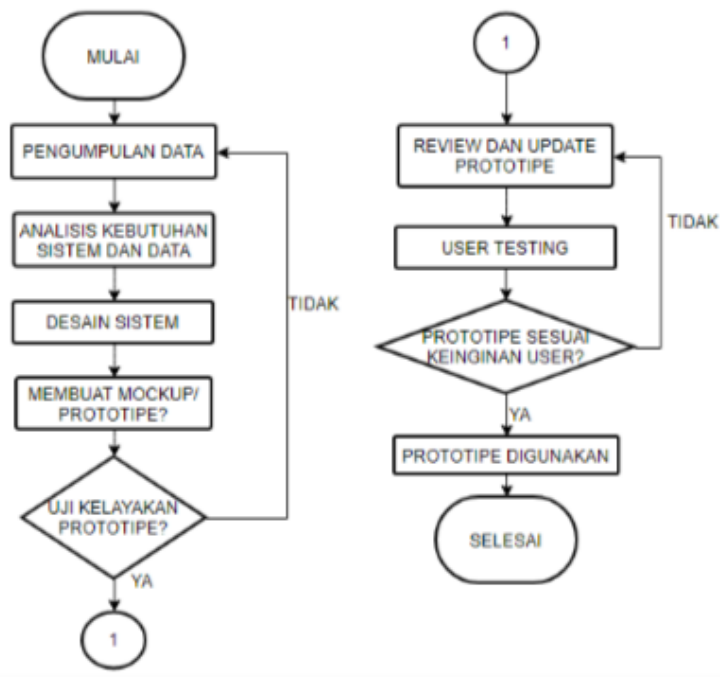

Gambar 1. Langkah Prototyping

\subsection{Pengumpulan Data}

Metode pengumpulan data yang dilakukan dalam penelitian ini terdiri dari:

a. Observasi : dilakukan pengamatan terhadap proses pengajuan outline mahasiswa yang terjadi di Program Studi Teknik Informatika Pontianak.

b. Wawancara : dilakukan tanya jawab kepada kaprodi dan admin mengenai alur prosedur pengajuan outline mahasiswa.

c. Studi Kepustakaan : dilakukan dengan mencari sumber referensi terkait topik penelitian

\subsection{Analisa Kebutuhan Sistem}

\subsubsection{Analisa Sistem Berjalan}

Pada saat ini proses pengelolaan skripsi mahasiswa masih dilakukan secara konvensional yang dapat dideskripsikan sebagai berikut;

a. Mahasiswa mengajukan judul tugas akhir berupa draft proposal skipsi. 
b. Mahasiswa mendaftar dan mengupload draft proposal melalui google form

c. Draft yang masuk akan dilakukan pengecekan kemiripan artikel, apabila hasil pengecekan kemiripan artikel $>30 \%$ maka judul proposal akan ditolak.

d. Draft yang sudah lolos pengecekan artikel kemudian akan diberikan tim dosen penguji.

e. Kaprodi kemudian akan memvalidasi draft outline kemudian dilakukan penjadwalan seminar proposal.

f. Pelaksanaan seminar proposal tugas akhir mahasiswa

g. Pemberian keputusan dan distribusi dosen pembimbing

h. Revisi Proposal Outline

\subsubsection{Analisa Kebutuhan Sistem dan Data \\ Kebutuhan fungsional sistem terdiri} dari :

1. Analisa kebutuhan antarmuka

a) Sistem menampilkan halaman upload proposal mahasiswa

b) Terdapat fitur untuk melakukan diskusi tanya jawab

2. Analisa kebutuhan data

Ditentukan beberapa variable penelitian diantaranya adalah: Data proposal, data mahasiswa, data dosen, data penilaian proposal, data jadwal seminar.

\subsubsection{Perancangan Sistem}

Perancangan sistem dibuat menggunakan alat bantu berupa Unified Modelling Language (UML) yang terdiri dari:

\section{a. Use Case Diagram}

Use Case diagram digunakan untuk mendeskripsikan interaksi dari setiap aktor yang terlibat di dalam sistem sehingga dapat diketahui siapa saja yang bisa mengakses sistem dan fungsi apa saja 48 yang dapat diakses oleh aktor tersebut (Fowler, 2004).

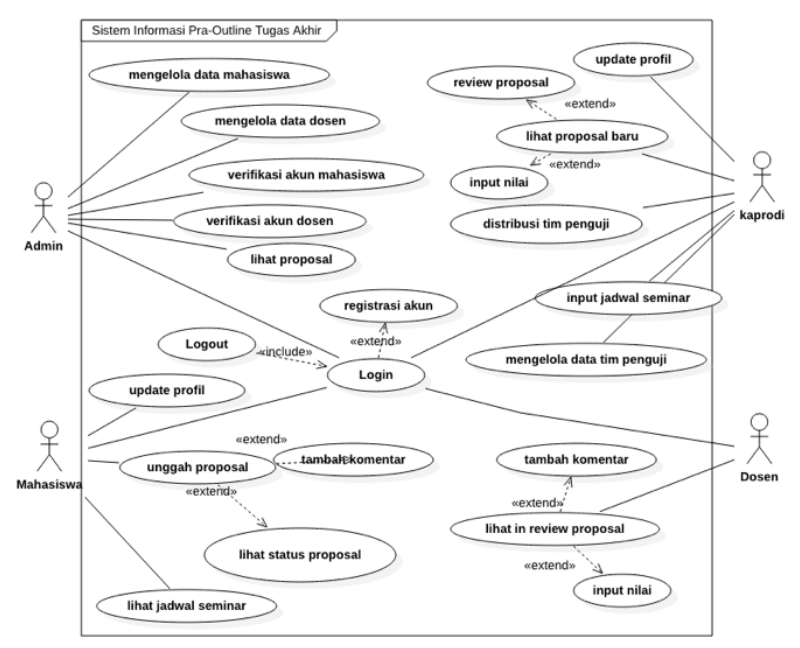

Gambar 2 Use Case Diagram Sistem Outline Mahasiswa

Terdapat 4 Aktor yang dapat mengakses sistem diantaranya adalah Mahasiswa, Dosen, Admin, dan Kaprodi. Admin dapat melakukan login. Setelah login berhasil, maka admin dapat mengelola data mahasiswa, mengelola data dosen, memverifikasi akun mahasiswa, memverifikasi akun dosen, melihat data proposal mahasiswa. Kemudian mahasiswa dapat melakukan update profil mahasiswa, unggah draft proposal, tambah komentar,lihat status proposal, lihat jadwal seminar proposal.

Dosen dapat melihat proposal mahasiswa, menambahkan komentar/review, memberikan nilai proposal. Sementara kaprodi dapat mengupdate profil, melihat data proposal baru, mereview proposal, distribusi tim penguji proposal, mengelola data tim penguji.

\section{b. Activity Diagram}

Activity Diagram menggambarkan aliran kerja aktifitas (work flow) dari proses bisnis yang ada dalam sistem. Berikut ini merupakan diagram aktifitas yang menggambarkan beberapa proses bisnis yang dapat dilihat pada gambar 3 dan 4 berikut.

p-ISSN : 2502-5724; e-ISSN : 2541-5735 


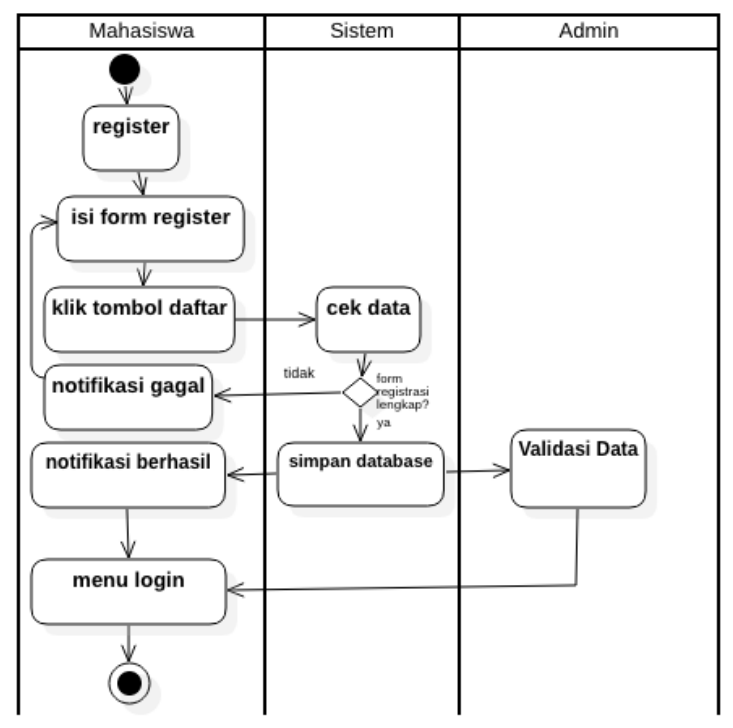

Gambar 3 Activity Diagram Proses Register Akun

Gambar 3 merupakan diagram aktifitas untuk proses pendaftaran mahasiswa. Mahasiswa akan mengisikan data berupa nama,nim,tgl lahir pada form register kemudian mengklik tombol daftar, kemudian sistem mengecek kelengkapan data registrasi. Apabila data lengkap maka akan muncul notifikasi berhasil, sebaliknya mahasiswa akan mengulang untuk mengisikan data registrasi. Admin kemudian memvalidasi data mahasiswa yang berhasil registrasi, setelah itu mahasiswa dapat masuk ke sistem melalui menu login.

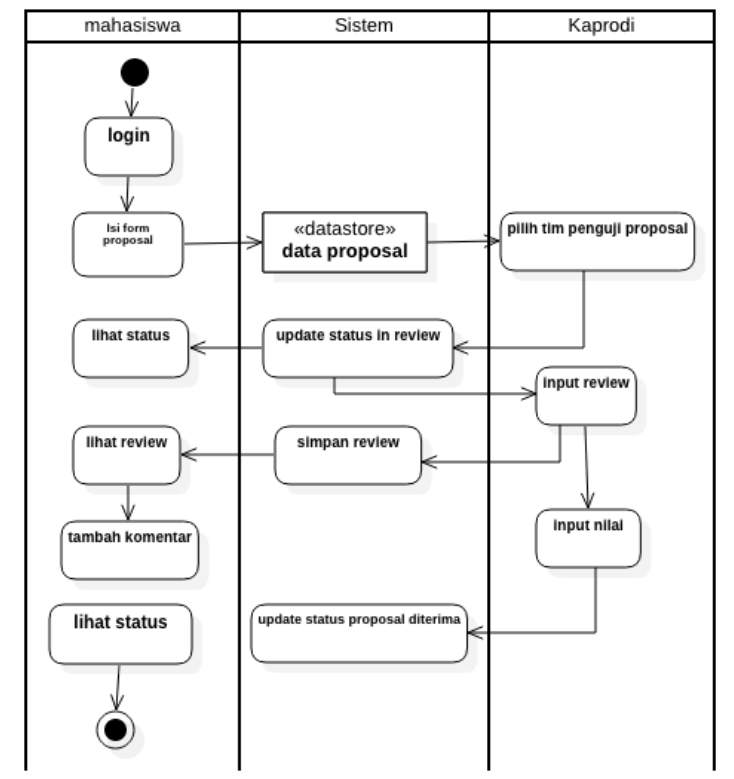

Gambar 4 Activity Diagram Proses Review Proposal
Gambar 4 merupakan diagram aktifitas pada proses review proposal. Mahasiswa login kedalam sistem kemudian mengisikan form proposal, data proposal yang telah disimpan dalam sistem kemudian dapat diakses oleh Kaprodi. Setelah itu kaprodi memilih tim penguji dan status proposal akan berubah menjadi in review.

\subsubsection{Perancangan Basis Data}

Perancangan basis data sistem digambarkan dalam bentuk ERD (Entity Relational Diagram). Rancangan basis data terdiri dari 6 tabel diantaranya adalah tbl_proposal,tbl_user,tbl_team,team_detail, penilaian_proposal,dan nilai_detail_proposal.

Berikut merupakan diagram relasi antar tabel yang dapat dilihat pada gambar 5 berikut.

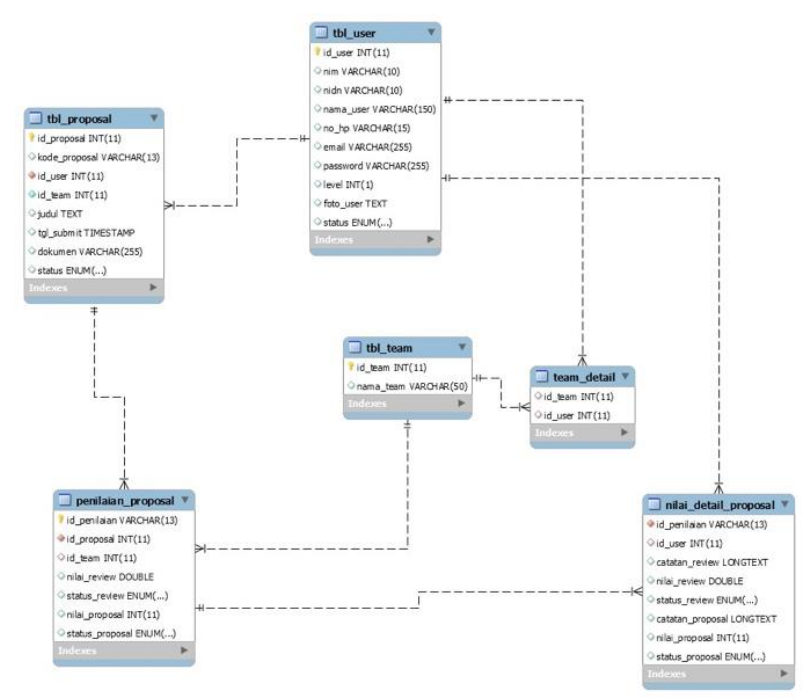

Gambar 5. ERD Sistem Pra-Outline Mahasiswa

\section{Hasil Dan Pembahasan}

Hasil pelaksanaan penelitian berupa prototype Sistem Informasi Manajemen Tugas Akhir berbasis web yang dibuat dengan menggunakan Framework Code Ignitier (Cl). Sistem terdiri dari 4 levelisasi akun diantaranya adalah Akun Mahasiswa, Akun Dosen, Akun Kaprodi, dan Admin. Halamanawal dari 
Sistem Manajemen Tugas Akhir dapat dilihat pada Gambar 6 berikut.

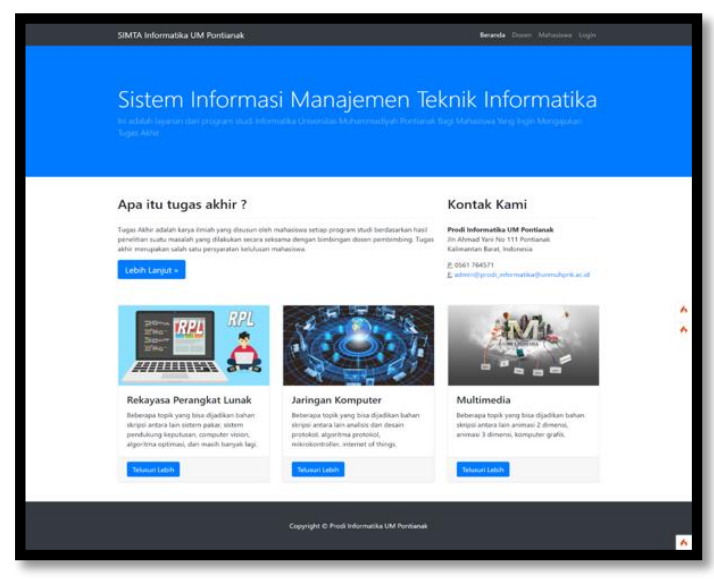

Gambar 6 Halaman Beranda Sistem Pra-Outline Mahasiswa

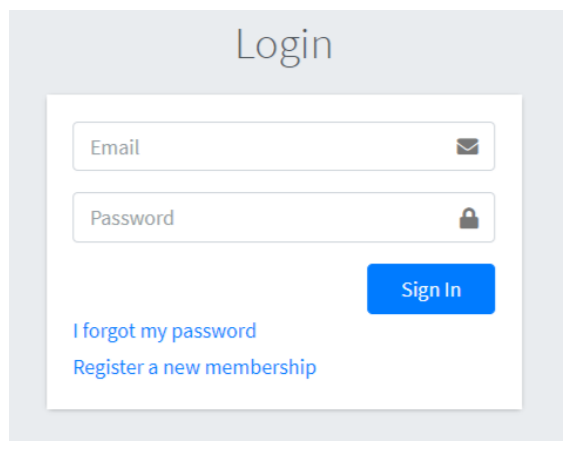

Gambar 7. Form Login Pengguna

Gambar 7 merupakan tampilan login pengguna, pengguna akan diarahkan ke halaman dashboard pengguna masingmasing.

Akun adminstrator dapat mengelola data mahasiswa dan dosen, melihat informasi jumlah status proposal skripsi yang sudah diupload mahasiswa, serta jumlah skripsi yang sudah masuk ke sistem seperti yang terlihat pada Gambar 8 berikut.

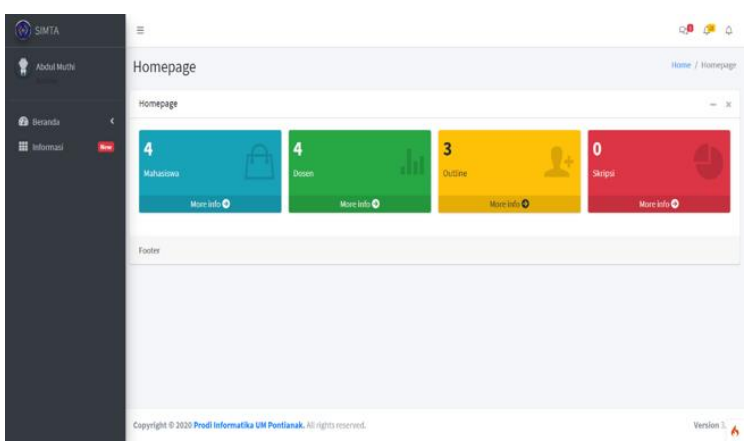

Gambar 8. Halaman Dashboard Admin
Sedangkan akun mahasiswa dapat melakukan unggah proposal, lihat jadwal seminar, status proposal, dan menu bimbingan seperti yang terlihat pada Gambar 9 berikut.

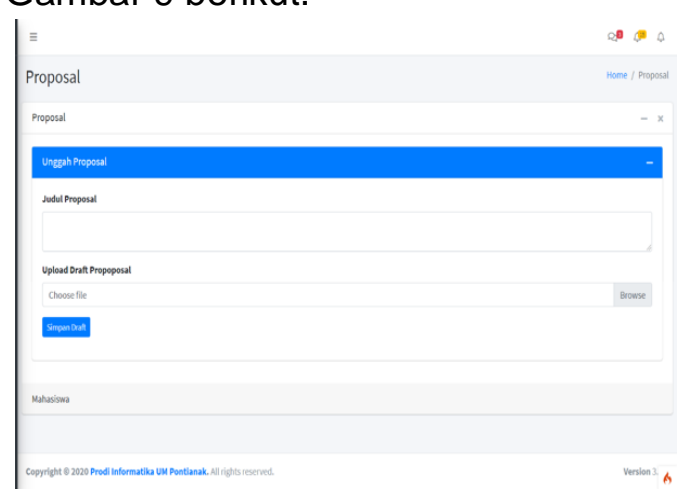

Gambar 9. Menu Unggah Proposal

Mahasiswa yang telah terverifikasi oleh admin, kemudian dapat mengunggah proposal dalam format pdf. Apabila proposal berhasil diunggah maka status proposal akan berubah menjadi submitted.

Status proposal mahasiswa terdiri dari 4 kategori yaitu baru diunggah (submitted), sedang ditinjau (in-review), lolos diseminarkan (waiting for seminar), dan ditolak (rejected).

Proposal yang telah diunggah akan masuk ke halaman Kaprodi untuk ditinjau dan didistribusikan kepada tim penguji dosen yang sesuai dengan materi proposal. Tim penguji yang terdiri dari 4 orang dosen kemudian akan mereview proposal dan memberikan nilai seperti yang terlihat pada Gambar 10 dan Gambar 11. 


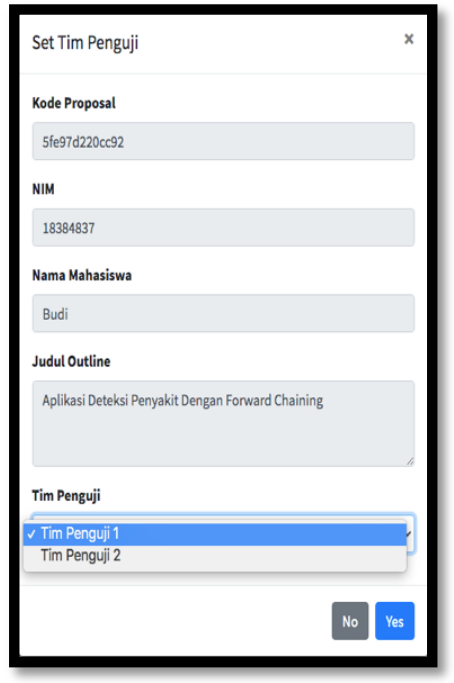

Gambar 10. Menu Distribusi Dosen Penguji

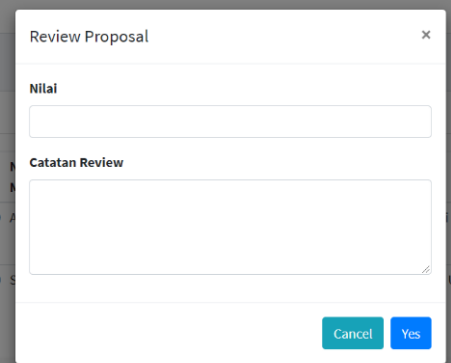

Gambar 11. Input Review dan Nilai Proposal

Selanjutnya, mahasiswa dapat melakukan konsultasi kepada tim dosen penguji apabila status proposal telah berubah menjadi in review. Berikut ini merupakan tampilan dari halaman konsultasi proposal yang terlihat pada Gambar 12.

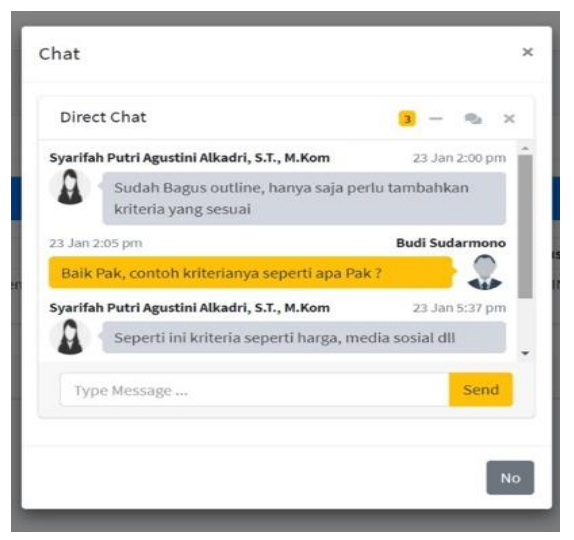

Gambar 12. Konsultasi Proposal

Tim penguji kemudian akan meninjau dan memberi nilai kelayakan proposal. p-ISSN : 2502-5724; e-ISSN : 2541-5735
Proposal dinyatakan lolos dan maju ke tahap seminar apabila mendapatkan rerata nilai $>70$. Apabila kurang dari itu, maka mahasiswa dapat mulai mengusulkan kembali dengan pertimbangan perubahan judul atau perbaikan metode pada proposalnya. Proposal yang telah lolos tersebut kemudian akan diberikan jadwal seminar oleh Kaprodi seperti yang terlihat pada Gambar 13 berikut. Mahasiswa dapat melihat informasi jadwal seminar melalui menu notifikasi yang ada pada akun mahasiswa. Hal ini dapat terlihat pada Gambar 14.

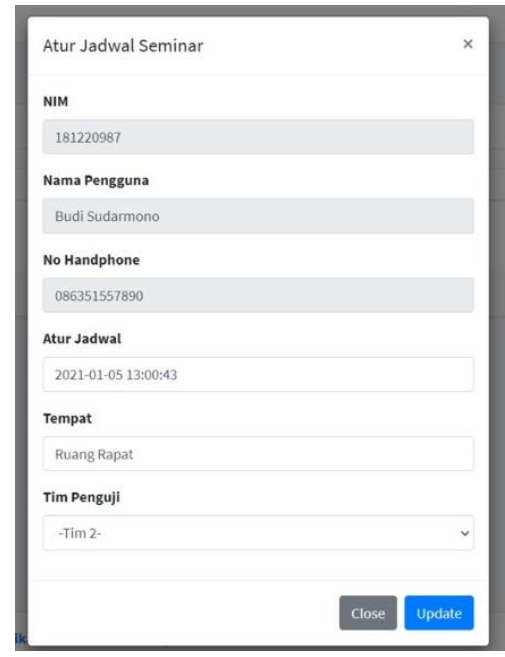

Gambar 13. Penetapan Jadwal dan Ruang Seminar

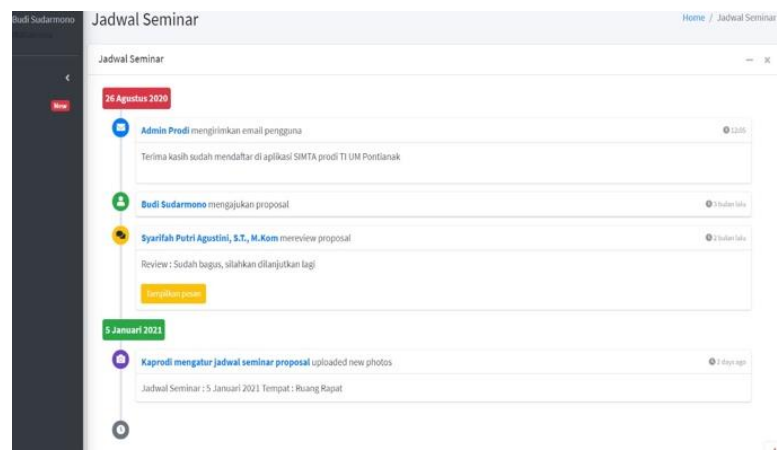

Gambar 14. Lihat Jadwal Seminar (Akun Mahasiswa)

Pengujian menggunakan metode pengujian blackbox dan User Acceptance Test (UAT).Pengujian Black Box dilakukan untuk melihat kesesuaian fungsionalitas dari aplikasi yang telah dibangun sementara UAT digunakan untuk 
mengetahui tingkat penerimaan pengguna terhadap sistem yang dibangun.

Tabel 1. Pengujian Blackbox

\begin{tabular}{|c|c|c|c|c|}
\hline No & $\begin{array}{c}\text { Fungsi } \\
\text { yang } \\
\text { diuji }\end{array}$ & $\begin{array}{l}\text { Skenario } \\
\text { Pengujian }\end{array}$ & $\begin{array}{c}\text { Hasil Yang } \\
\text { diujikan }\end{array}$ & Status \\
\hline \multirow[t]{2}{*}{1.} & Login & $\begin{array}{l}\text { Mengisi data } \\
\text { pada form } \\
\text { login, } \\
\text { kemudian } \\
\text { mengklik } \\
\text { tombol Login. }\end{array}$ & $\begin{array}{l}\text { Proses } \\
\text { Berhasil, } \\
\text { Sistem } \\
\text { Menampilka } \\
\text { n Notifikasi. }\end{array}$ & \multirow[t]{2}{*}{ Valid } \\
\hline & & $\begin{array}{l}\text { Mengosongka } \\
\mathrm{n} \text { isi data pada } \\
\text { form login, } \\
\text { kemudian } \\
\text { mengklik } \\
\text { tombol Login }\end{array}$ & $\begin{array}{l}\text { Proses } \\
\text { Gagal, } \\
\text { Sistem } \\
\text { Menampilka } \\
\text { n pesan } \\
\text { kesalahan. }\end{array}$ & \\
\hline 2. & $\begin{array}{l}\text { Pendaft } \\
\text { aran } \\
\text { Akun } \\
\text { Baru }\end{array}$ & $\begin{array}{l}\text { Mengisi } \\
\text { keseluruhan } \\
\text { data } \\
\text { pengguna } \\
\text { kemudian } \\
\text { mengklik } \\
\text { tombol } \\
\text { Simpan. } \\
\end{array}$ & $\begin{array}{l}\text { Proses } \\
\text { Berhasil, } \\
\text { Sistem } \\
\text { menampilka } \\
\text { n pesan } \\
\text { notifikasi. }\end{array}$ & Valid \\
\hline 4. & $\begin{array}{l}\text { Upload } \\
\text { Draft } \\
\text { Proposal }\end{array}$ & $\begin{array}{l}\text { Mahasiswa } \\
\text { menuliskan } \\
\text { judul proposal } \\
\text { skripsi, } \\
\text { kemudia } \\
\text { mengupload } \\
\text { file proposal } \\
\text { dalam format } \\
\text { PDF. }\end{array}$ & $\begin{array}{l}\text { Proses } \\
\text { Berhasil, } \\
\text { Sistem } \\
\text { Menampilka } \\
\text { n pesan } \\
\text { notifikasi } \\
\text { dan } \\
\text { menampilka } \\
\text { n hasil } \\
\text { unggahan } \\
\text { proposal. }\end{array}$ & Valid \\
\hline 5. & $\begin{array}{l}\text { Review } \\
\text { Proposal }\end{array}$ & $\begin{array}{l}\text { Mengisikan } \\
\text { komentar dan } \\
\text { nilai proposal. }\end{array}$ & $\begin{array}{l}\text { Proses } \\
\text { Berhasil, } \\
\text { Komentar } \\
\text { dan Nilai } \\
\text { tersimpan. }\end{array}$ & Valid \\
\hline 6. & $\begin{array}{l}\text { Input } \\
\text { Jadwal } \\
\text { Seminar } \\
\text { Proposal } \\
\text {. }\end{array}$ & $\begin{array}{l}\text { Memilih daftar } \\
\text { proposal yang } \\
\text { disetujui, } \\
\text { kemudian } \\
\text { memilih } \\
\text { tanggal } \\
\text { seminar. }\end{array}$ & $\begin{array}{l}\text { Proses } \\
\text { Berhasil, } \\
\text { jadwal } \\
\text { seminar } \\
\text { proposal } \\
\text { mahasiswa } \\
\text { tersimpan }\end{array}$ & Valid \\
\hline 7. & $\begin{array}{l}\text { Verifikas } \\
\text { i Akun } \\
\text { Mahasis } \\
\text { wa }\end{array}$ & $\begin{array}{l}\text { Memilih data } \\
\text { mahasiswa } \\
\text { yang telah } \\
\text { registrasi ke } \\
\text { sistem. }\end{array}$ & $\begin{array}{l}\text { Proses } \\
\text { berhasil. }\end{array}$ & Valid \\
\hline 8. & $\begin{array}{l}\text { Verifikas } \\
\text { i Akun } \\
\text { Dosen }\end{array}$ & $\begin{array}{l}\text { Memilih data } \\
\text { dosen yang } \\
\text { telah registrasi } \\
\text { ke sistem. }\end{array}$ & $\begin{array}{l}\text { Proses } \\
\text { berhasil. }\end{array}$ & Valid \\
\hline
\end{tabular}

\begin{tabular}{|l|l|l|l|l|}
\hline 9. & $\begin{array}{l}\text { Lihat } \\
\text { detil } \\
\text { Proposal } \\
.\end{array}$ & $\begin{array}{l}\text { Memilih data } \\
\text { proposal } \\
\text { mahasiswa, } \\
\text { dan melihat } \\
\text { detil proposal. }\end{array}$ & $\begin{array}{l}\text { Proses } \\
\text { berhasil. }\end{array}$ & Valid \\
& & \\
\hline
\end{tabular}

Responden yang digunakan dalam pengujian ini adalah 10 orang Dosen dan 30 orang mahasiswa Prodi Teknik Informatika. Responden akan diberikan jenis pertanyaan yang berbeda sesuai dengan tingkatan pengguna dalam sistem. Setiap jawaban memiliki bobot skor yang kemudian akan dihitung sebagai persentase untuk acuan tingkat kepuasan pengguna. Bobot yang dipergunakan mengacu kepada skala likert yang dapat dilihat pada tabel 2 berikut.

Tabel 2. Skala Likert

\begin{tabular}{|c|c|}
\hline Skor & Keterangan \\
\hline 1 & Sangat Tidak Setuju (STS) \\
\hline 2 & Tidak Setuju (TS) \\
\hline 3 & Netral (N) \\
\hline 4 & Setuju (S) \\
\hline 5 & Sangat Setuju (SS) \\
\hline
\end{tabular}

Hasil perhitungan tingkat kepuasan pengguna akan disesuaikan dengan tabel interpretasi skala likert yang menunjukkan tingkat usability dari pengguna seperti yang terlihat pada tabel 3 berikut.

Tabel 3. Interpretasi Skala Likert

\begin{tabular}{|c|c|}
\hline Skor dengan interval 20 & Keterangan \\
\hline $0 \%-19 \%$ & Sangat tidak memuaskan \\
\hline $20 \%-39 \%$ & .Tidak memuaskan \\
\hline $40 \%-59 \%$ & Biasa \\
\hline $60 \%-79 \%$ & Memuaskan \\
\hline $80 \%-100 \%$ & Sangat Memuaskan \\
\hline
\end{tabular}

Berikut ini merupakan hasil rekap jawaban kuisioner berdasarkan tingkat penerimaan dosen yang dapat dilihat pada tabel 4 berikut. 
Tabel 4. Pengujian UAT untuk dosen Prodi Teknik Informatika UM Pontianak

\begin{tabular}{|c|c|c|c|c|c|c|}
\hline \multirow[t]{2}{*}{ No } & \multirow[t]{2}{*}{ Pernyataan } & \multicolumn{5}{|c|}{ Jawaban } \\
\hline & & SS & $\mathrm{S}$ & $\mathrm{N}$ & TS & STS \\
\hline 1 & $\begin{array}{l}\text { Fitur sistem } \\
\text { dapat mengelola } \\
\text { data pengguna } \\
\text { dengan baik. }\end{array}$ & 9 & 1 & 0 & 0 & 0 \\
\hline 2 & $\begin{array}{l}\text { Fitur sistem } \\
\text { dapat mengelola } \\
\text { data } \\
\text { komentar/review } \\
\text { dari tim penguji. }\end{array}$ & 10 & 0 & 0 & 0 & 0 \\
\hline 3 & $\begin{array}{l}\text { Fitur sistem } \\
\text { dapat } \\
\text { menampilkan } \\
\text { status proposal } \\
\text { outline dengan } \\
\text { baik }\end{array}$ & 8 & 2 & 0 & 0 & 0 \\
\hline 4 & $\begin{array}{l}\text { Fitur sistem } \\
\text { dapat } \\
\text { menampilkan } \\
\text { notifikasi } \\
\text { review/komentar } \\
\text { terbaru dengan } \\
\text { baik. }\end{array}$ & 1 & 6 & 3 & 0 & 0 \\
\hline 5 & $\begin{array}{l}\text { Tampilan } \\
\text { navigasi pada } \\
\text { sistem mudah } \\
\text { dipahami. }\end{array}$ & 4 & 5 & 1 & 0 & 0 \\
\hline 6 & $\begin{array}{lr}\text { Apakah } & \text { aplikasi } \\
\text { telah } & \text { sesuai } \\
\text { dengan } & \text { proses } \\
\text { bisnis } & \text { yang } \\
\text { berlaku? } & \\
\end{array}$ & 6 & 3 & 1 & 0 & 0 \\
\hline & JUMLAH & 38 & 17 & 5 & 0 & 0 \\
\hline
\end{tabular}

Berdasarkan jumlah jawaban responden dosen maka skor kepuasan pengguna (UAT) dapat dihitung pada tabel 5 berikut.

Tabel 5. Perhitungan Skor UAT Pengguna Dosen

\begin{tabular}{|c|l|c|c|c|c|}
\hline No & Kategori & $\begin{array}{l}\text { Juml } \\
\text { ah }\end{array}$ & $\begin{array}{c}\text { Bobot } \\
\text { Likert }\end{array}$ & $\begin{array}{c}\text { Skor= } \\
(\text { Jumla } \\
\mathrm{h}^{*} \text { Bob } \\
\text { ot }\end{array}$ & $\begin{array}{c}\text { Persentase }= \\
\text { (Skor/Total } \\
\text { Skor) }{ }^{*} 100 \%\end{array}$ \\
\hline 1 & $\begin{array}{l}\text { Sangat } \\
\text { Setuju } \\
\text { (SS) }\end{array}$ & 38 & 5 & 190 & 70 \\
\hline 2 & $\begin{array}{l}\text { Setuju } \\
\text { (S) }\end{array}$ & 17 & 4 & 68 & 25 \\
\hline 3 & $\begin{array}{l}\text { Netral } \\
\text { (N) }\end{array}$ & 5 & 3 & 15 & 5 \\
\hline 4 & $\begin{array}{l}\text { Tidak } \\
\text { Setuju } \\
\text { (TS) }\end{array}$ & 0 & 2 & 0 & 0 \\
\hline 5 & $\begin{array}{l}\text { Sangat } \\
\text { Tidak } \\
\text { Setuju }\end{array}$ & 0 & 1 & 0 & 0 \\
\hline
\end{tabular}

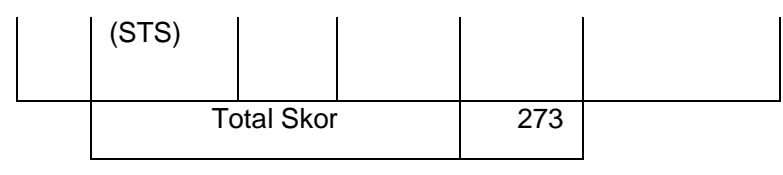

Hasil jawaban dari responden sebanyak 30 orang kemudian dapat dihitung nilai tertinggi dan terendah seperti berikut.

Nilai tertinggi $=10 \times 6 \times 5=300$

Nilai terendah $=10 \times 6 \times 1=60$

Berdasarkan perhitungan yang menyatakan nilai tertinggi adalah 300 dapat dicari persentase seperti berikut.

$$
\begin{aligned}
\text { Persentase } & =\text { Jumlah total skor / Nilai } \\
& \text { tertinggi } \times 100 \% \\
& =273 / 300 \times 100 \% \\
& =91 \%
\end{aligned}
$$

Tingkat usability sistem berdasarkan jawaban responden sebanyak 10 orang dan indeks persentase diatas menunjukkan $91 \%$ yang artinya sangat memuaskan.

Pengujian UAT berdasarkan tingkat kepuasan mahasiswa dapat dilihat hasil rekap jawaban kuisioner yang dapat dilihat pada tabel 6 berikut.

Tabel 6. Pengujian UAT untuk Mahasiswa Prodi Teknik Informatika UM Pontianak

\begin{tabular}{|c|l|c|c|c|c|c|}
\hline \multirow{2}{*}{ No } & \multirow{2}{*}{ Pernyataan } & \multicolumn{4}{|c|}{ Jawaban } \\
\cline { 3 - 6 } 1 & SS & S & N TS & STS \\
\hline & $\begin{array}{l}\text { Proses } \\
\text { Pendaftaran } \\
\text { akun pengguna } \\
\text { mudah } \\
\text { dipahami. }\end{array}$ & 25 & 5 & 0 & 0 & 0 \\
\hline $\begin{array}{l}\text { Form proposal } \\
\text { dapat diisi } \\
\text { dengan singkat. }\end{array}$ & 10 & 18 & 2 & 0 & 0 \\
\hline 3 & $\begin{array}{l}\text { Sistem dapat } \\
\text { menampilkan } \\
\text { komentar/review } \\
\text { dari dosen. }\end{array}$ & 25 & 3 & 2 & 0 & 0 \\
\hline
\end{tabular}




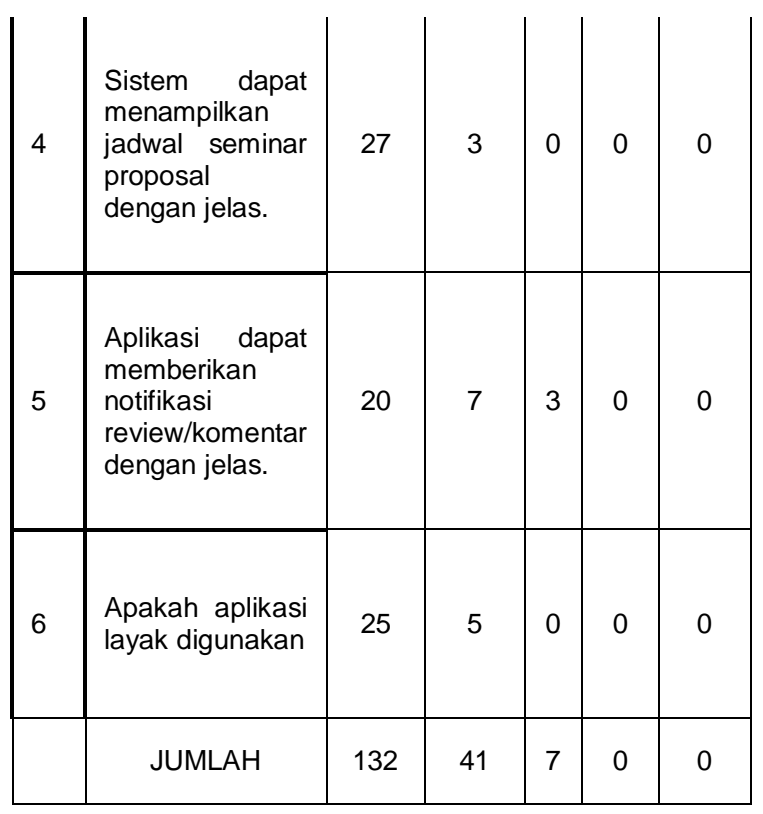

Berdasarkan jumlah jawaban responden mahasiswa maka skor kepuasan pengguna (UAT) dapat dihitung pada tabel 7 berikut.

Tabel 7. Pengujian UAT untuk Mahasiswa UM Pontianak

\begin{tabular}{|c|l|c|c|c|c|}
\hline No & Kategori & Jumlah & $\begin{array}{c}\text { Bobot } \\
\text { Likert }\end{array}$ & $\begin{array}{c}\text { Skor= } \\
\text { (Jumlah } \\
{ }^{*} \text { Bobot) }\end{array}$ & $\begin{array}{c}\text { Persentase } \\
=(\text { Skor/Total } \\
\text { Skor) }{ }^{*} 100 \%\end{array}$ \\
\hline 1 & $\begin{array}{l}\text { Sangat } \\
\text { Setuju } \\
\text { (SS) }\end{array}$ & 132 & 5 & 660 & 78 \\
\hline 2 & $\begin{array}{l}\text { Setuju } \\
\text { (S) }\end{array}$ & 42 & 4 & 168 & 20 \\
\hline 3 & $\begin{array}{l}\text { Netral } \\
\text { (N) }\end{array}$ & 7 & 3 & 21 & 2 \\
\hline 4 & $\begin{array}{l}\text { Tidak } \\
\text { Setuju } \\
\text { (TS) }\end{array}$ & 0 & 2 & 0 & 0 \\
\hline 5 & $\begin{array}{l}\text { Sangat } \\
\text { Tidak } \\
\text { Setuju } \\
\text { (STS) }\end{array}$ & 0 & 1 & 0 & 0 \\
\hline & & & 849 & \\
\cline { 2 - 5 } & Total Skor & & & \\
\hline
\end{tabular}

Perhitungan skor UAT menunjukkan bahwa responden dosen yang menjawab Sangat Setuju (SS) yaitu $70 \%$, dan yang menjawab Setuju (S) yaitu 25\%, sedangkan yang menjawab Netral (N) sebesar $5 \%$, sedangkan pengujian yang dilakukan oleh responden mahasiswa menunjukkan tingkat kepuasan Sangat
Setuju (SS) sebesar 78\%,Setuju (S) sebesar $20 \%$, dan Netral (N) sebesar $2 \%$.

Hasil jawaban dari responden sebanyak 30 orang kemudian dapat dihitung nilai tertinggi dan terendah seperti berikut.

Nilai tertinggi $=30 \times 6 \times 5=900$

Nilai terendah $=30 \times 6 \times 1=180$

Berdasarkan perhitungan yang menyatakan nilai tertinggi adalah 900 dapat dicari persentase seperti berikut.

Persentase = Jumlah total skor / Nilai tertinggi $\times 100 \%$

$=875 / 900 \times 100 \%$

$=94 \%$

Tingkat usability sistem berdasarkan jawaban responden sebanyak 30 orang dan indeks persentase diatas menunjukkan $94 \%$ yang artinya sangat memuaskan.

Berdasarkan hasil pengujian UAT yang telah dilakukan ini diddapatkan hasil bahwa indeks kepuasan pengguna yaitu mahasiswa dan dosen $>80 \%$, hal ini menunjukkan bahwa Sistem Informasi PraOutline yang diujikan termasuk dalam Kategori Sangat Memuaskan dan dapat diterima oleh Mahasiswa dan Dosen Prodi Teknik Informatika UM Pontianak.

\section{Kesimpulan}

Berdasarkan hasil analisis, implementasi, dan pengujian yang telah dilakukan, maka dapat ditarik beberapa kesimpulan yaitu Sistem Informasi PraOutline Tugas akhir mempermudah mahasiswa dan dosen dalam melakukan proses bimbingan tugas akhir. Hasil yang diperoleh untuk pengujian UAT menunjukkan lebih dari $80 \%$ yang menunjukkan bahwa Sistem Informasi Pra-Outline termasuk dalam Kategori Sangat Memuaskan dan dapat diterima oleh Mahasiswa dan Dosen Prodi Teknik Informatika UM Pontianak, Kemudian 
berdasarkan hasil pengujian blackbox menunjukkan keseluruhan fungsional sistem dapat berjalan dengan baik dan sesuai yang diharapkan.

Sistem Informasi Pra-Outline Tugas Akhir dapat digunakan untuk memonitoring judul tugas akhir mahasiswa yang diajukan oleh mahasiswa sehingga tidak terjadi duplikasi judul.

Sistem Informasi Pra-Outline Tugas Akhir dalam pengembangannya diharapkan dapat memanajemen keseluruhan data bimbingan Skripsi mahasiswa hingga tahap akhir dan terintegrasi dengan sistem penilaian sidang skripsi mahasiswa, selain itu dapat ditambahkan fitur push notification sebagai pemberitahuan secara real time agar memudahkan mahasiswa dan dosen mendapatkan informasi proposal/ komentar terbaru.

\section{DAFTAR PUSTAKA}

Almahfud. (2020). Berjuang Menyelesaikan skripsi ditengah pandemi.

Fowler, M. (2004). UML Distilled: A Brief Guide to the Standard Object Modeling Language. Pearson Paravia Bruno Mondad.

Kusumaningrum, A. D. (2011). Sistem informasi penilaian kinerja dosen di sekolah tinggi ilmu kesehatan telogorejo semarang. Jurusan Sistem Informasi Fakultas IImu Komputer Universitas Dian Nuswantoro, (5).

Pressman, R. S. (2014). SOFTWARE ENGINEERING: A PRACTITIONER'S APPROACH, SEVENTH EDITION. In Software Quality Engineering: A Practitioner's Approach.

Putra, S., \& Kumaladewi, N. (2012). Sistem Informasi Evaluasi Kinerja Dosen (Studi Kasus: Fakultas Sains dan Teknologi Universitas Islam Negeri Syarif Hidayatullah Jakarta). Studia Informatika: Jurnal Sistem Informasi, 4(2), 1-5. https://doi.org/10.15408/sijsi.v4i2.133

Sutabri, T. (2012). Konsep Sistem Informasi. In Jurnal Administrasi Pendidikan UPI.
Teknik, T. P. F. (2014). Pedoman Penulisan Skripsi Fakultas Teknik. Pontianak: Universitas Muhammadiyah Pontianak.

Tuturoong, F. M., Sengkey, R., \& Najoan, X. (2016). Rancang Bangun Sistem Informasi Proses Tugas Akhir. Jurnal Teknik Informatika, 8(1). https://doi.org/10.35793/jti.8.1.2016.12 228 